\title{
Appliance Analysis
}

RCDP Cycle 2

MAY I 199

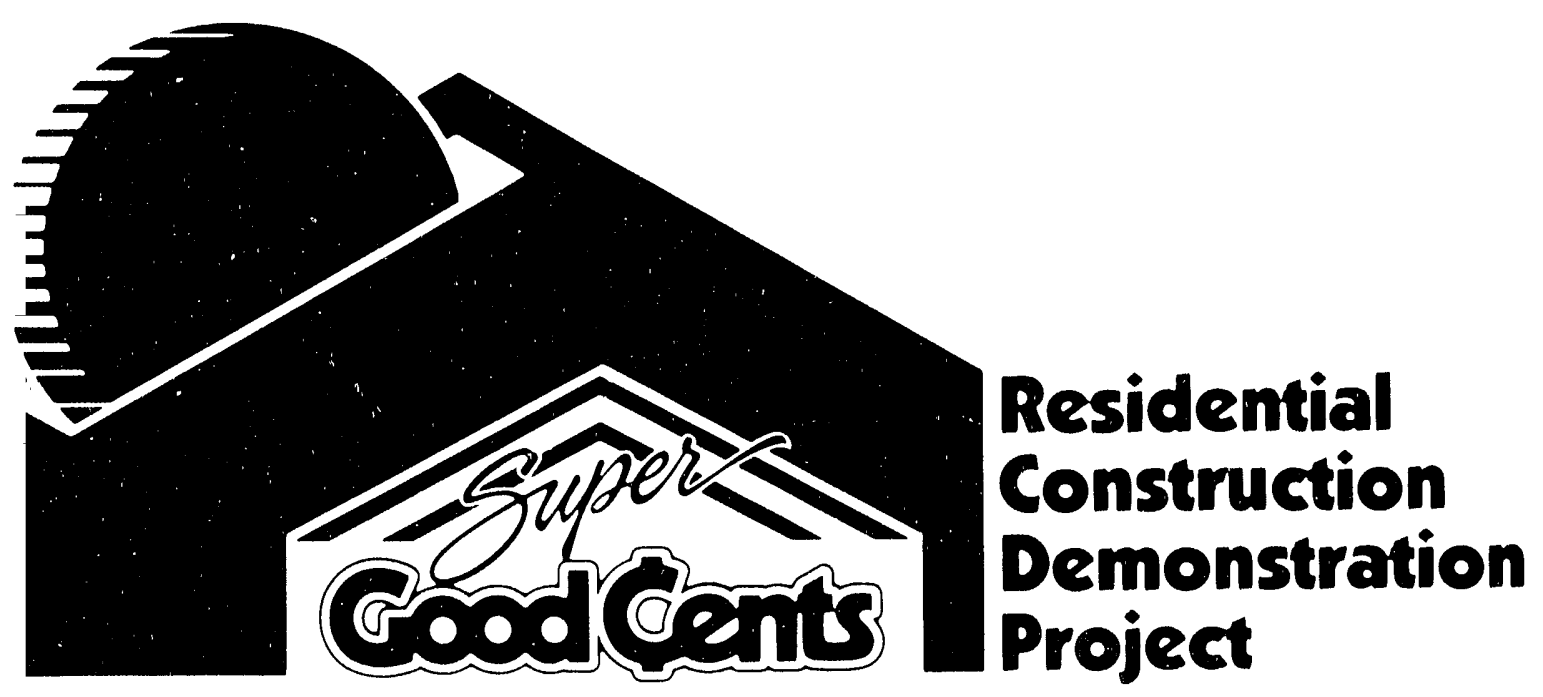




\section{Disclaimer}

This report was prepared as an account of work sponsored by an agency of the Uniled States Government. Nether the Urited States Government nor any agency thereof. nor any of their employees, makes any warranty, express or implied, or assumes any legal liability or responsibility for the accuracy, completeness, or usefulness of any information, apparatus, product, or process disclosed, or represents that its use would not infringe privately owned rights. Reference herein to any specific commercial product, process, or service by trade name, trademark, manulacturer, or otherwise, does not necessarily constitute or imply its endorsement, recommendation, or favoring by the United States Government or any agency thereof. The views and opinions of authors expressed herein do not necessarily state or rellect those of the United Slates Government of any agency thereof. 


\title{
Appliance Analysis
}

\author{
Maureen Quaid \\ Rick Kunkle \\ Brian Lagerberg \\ Program Research Unit
}

August 1991 


\section{Contents}

\section{Acknowledgements}

\section{Executive Summary}

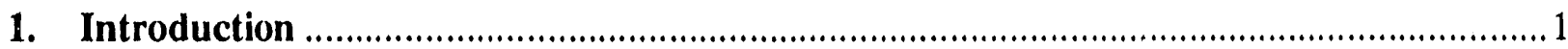

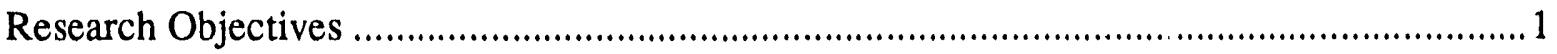

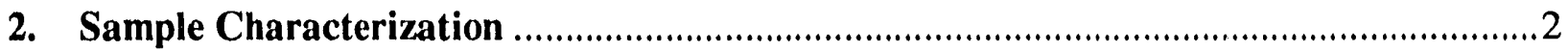

Appliance Efficiency Categories ............................................................................. 2

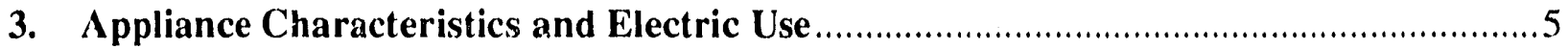

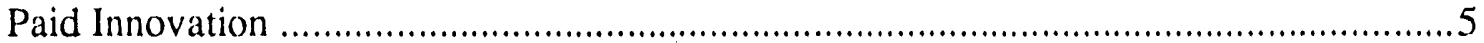

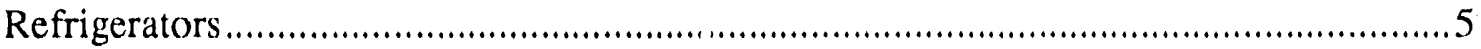

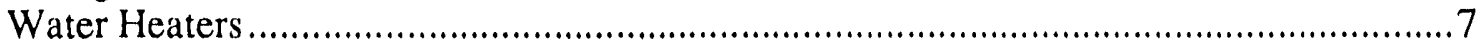

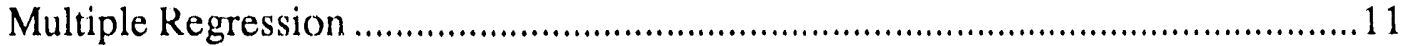

Monthly Use and End Use Load Factors .................................................. 12

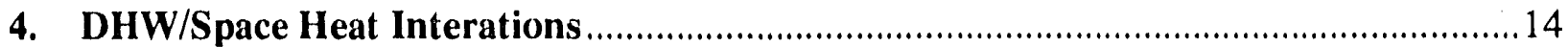

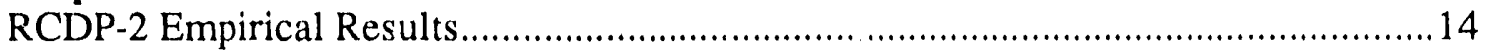

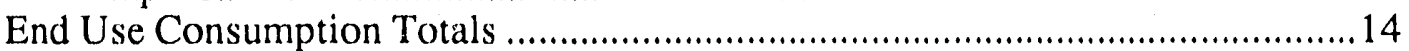

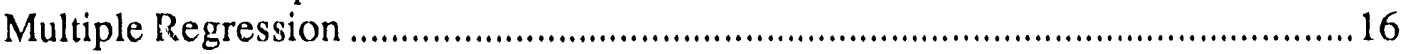

Modeling of Space Heat Interactions ............................................................ 16

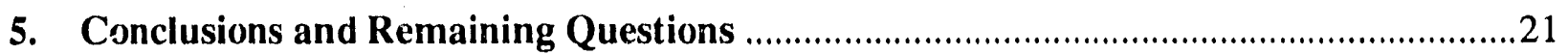

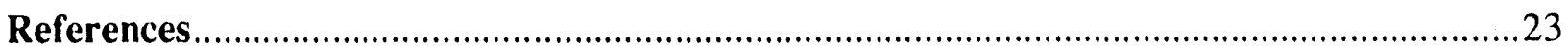

\section{Appendix}

\section{List of Figures}

Figure 1: Refrigerator Volume By Efficiency Class

Figures 2 and 3: Predicted Annual Refrigerator Cost by Efficiency Class

Figure 4: DHW Volurne By Efficiency Class

Figure 5: DHW Consumption: Zone 1 By Tank Size

Figure 6: DHW Use: By Number of Occupants

Figure 7: DHW Use: By Energy Factor Class

Figure 8: DHW Consumption By Energy Factor Class and Zone

Figure 9: Monthly DHW Consumption Zone 1

Figure 10: Monthly DHW Consumption Zone 2

Figure 11: Monthly DHW Consumption Zone 3

Figure 12: Monthly DHW Consumption All Zones

Figure 13: DHW Consumption By End Use: DHW/Space Heat/Other

Figure 14: End Uses 


\section{RCDP CYCLE 2 APPLIANCE ANALYSIS}

\section{Executive Summary}

The appliance use of RCDP-2 homes was analyzed to determine whether significant differences existed in houses that had efficient appliances (domestic hot water (DHW) and refrigerators) compared to those with appliances not considered efficient. Specific analyses addressed:

- DHW and refrigerator appliance end uses,

- Whole house and space heat energy use, and

- Interaction effects between appliance use and space heating energy use.

Major findings of the study were:

- It is difficult to verify the efficiency of app'iances installed in occupied homes. Consistent labeling by manufacturers of appliance energy use information would assist evaluators, and more importantly, consumers who want to make informed purchase decisions.

- Efficient appliances were not readily available at the time RCDP-2 was being implemented.

- The combination of a marketing and an acquisition program (Blue Clue and RCDP) led to minimal savings in the group considered to have efficient appliances, probably because of upgrades in size and features.

- In a comparison of conventional water heaters, differences in energy use based on EF were not significant when corrected for number of occupants. The sample size was small and the variance of the measured data was large enough that expected savings (305 kWh/year, based on NPPC estimates) were not be detectable.

- Number of occupants was the strongest empirical determinant of DHW energy use. NPPC estimates predict that savings due to efficient end uses $(688 \mathrm{kWh} /$ year from low flow showerheads, efficient dishwashers and clothes washers) are more than twice the savings from efficient tanks $(305 \mathrm{kWh} /$ year). We were unable to determine water use in this project.

- Exhaust air heat pump water heaters performed much better than cor ientional water heaters. Direct comparisons with conventional systems are complicated by the fact that these types of water heaters supply supplementary space heat.

- No detectable space heat interactions were found in the measured data. DOE-2 models based on typical conditions indicate that space heat interactions in many homes may be less than currently assumed. Factors leading to lower interactions include location of DHW in the garage, a central heating system, or high solar gains. Other factors, which were not modeled but which are found throughout the region, may also lead to lower interactions. 


\section{RCDP CYCLE 2 APPLIANCE ANALYSIS}

\section{INTRODUCTION}

As single family homes become more efficient relative to their space heating needs, the energy used by appliances will become an increasing proportion of these homes' total energy use. Programs have not linked appliance efficiency and shell efficiency until recently. Cycle II of the Residential Construction Demonstration Project (RCDP-2) offered incentives to builders for installing energy-efficient appliances in new homes in Washington, Oregon, Idaho, and Montana. Of the 183 homes built during this project in 1987 and 1988, about one-third were credited for having efficient water heaters, refrigerators, and dishwashers.

Qualifying refrigerators were required to meet specifications devised for the Bonneville Power Administration's "Blue Clue" program, which selects and piomotes the top 15 percent of energy efficient refrigerators and freezers. The Blue Clue list changes quarterly to reflect market changes. Water heaters were required to have energy factors (EF) of 0.93 or greater. Dishwashers were also included in the program, and qualifying models were listed in specifications developed by WSEO and BPA.

\section{Research Objectives}

One of the objectives of RCDP-2 was to quantify the energy use of efficient appliances. In addition to providing whole-house consumption data, homes were also sub-metered for water heater, refrigerator, space heating, and vent use. Site visits verified manufacturers, model numbers, and other attributes of installed appliances. The goal of this analysis is to determine the energy savings from efficient appliances, any offsetting effects in space heating needs, and whether efficient appliances are cost-effective investments. Specific research questions to be addressed are:

1. Is there a significant difference in whole house and space heat use between appliance efficiency homes and homes with an unrestricted mix of appliances?

2. Among RCDP-2 homes, is there a significant difference in hot water and refrigerator energy use between homes with and without efficient appliances?

3. If there are significant differences in appliance energy use, what is the magnitude of the interaction effect between appliance efficiency gains and space hening? What are the no: savings after accounting for inseraction effects?

4. What are the economics of varchasing energy efficient appliances for installation in srace heating efficient homes? How sensitive are the economics to changes ia key economis: parameters? 


\section{SAMPLE CHARACTERIZATION}

Altogether, 183 RCDP-2 homes were built. Most (171) had both site visit and sub-metered electric consumption data. Of these, 140 had at least 12 months of usable consumption data. Because of the difficulties in weather-normalizing sub-metered data, we equated annual consumption periods, where possible. Our final sample has 126 cases with the same year-long consumption period $(4 / 1 / 89-3 / 31 / 90)$, and 14 cases with annual consumption periods matched as closely as possible to the same time frame.

\section{Appliance Efficiency Categories}

Based on manufacturer and model numbers, and using our best judgment-as well as an exhaustive variety of source references ${ }^{1}$--we were able to classify the efficiency of 135 water heaters and 111 refrigerators. Manufacturer and model data on dishwashers were insufficient to classify these appliances, and furthermore, we did not have sub-metered consumption data for dishwashers. Since we did have sub-metered data on domestic hot water (DHW) and refrigerators, we focused our efforts on these two appliances.

Of those water heaters we were able to classify, 48 percent were efficient as defined by RCDP-2, that is, had energy factors of 0.93 or above. Among the refrigerators we were able to classify, 40 percent complied with Blue Clue standards, or had equivalent feature/efficiency pairings. When we combined groupings of both appliances, 19 percent of homes had both efficient water heaters and refrigerators (Table 2.1).

\section{Table 2.1 Appliance Efficiency Classifications}

\begin{tabular}{lccr} 
Appliances Classified & DHW & Refrigerator & Both \\
\hline Total & 135 & 111 & 108 \\
\hline Efficient & 65 & 44 & 21 \\
Percent Efficient & $48 \%$ & $4(0 \% 19 \%$ &
\end{tabular}

Appliance efficiency innovation credits were paid to builders for 43 percent of RCDP-2 houses. Contractors who wanted to receive payment for the appliance efficiency innovation were required to verify that they had installed efficient appliances--with energy guide labels or invoices. Based on the original program criteria, 28 percent of payments went to contractors who built houses that had efficient DHW and refrigerators; 45 percent went to contractors who installed one or the other efficient appliance; and 24 percent of payments went to contractors who did not install either efficient appliance (Table 2.2).

1 References included several time-specific versions (1985-199()) of the GAMA directory, the AHAM directory, and the Blue Clue listings. We also used the RCDP-2 specifications, the DHW listing prepared by WSEO (Gordon and Born, 1989), and information from several manufacturers whom we contacted directly to resolve questions about model numbers not found in any other source. 
Table 2.2 Appliance Eifriciency vs Paid Innovation

(Where Efriciencies of Both Appliances are Classified)

\begin{tabular}{lccccc} 
Paid & $\begin{array}{r}\text { Both } \\
\text { Efficient }\end{array}$ & $\begin{array}{r}\text { DHW } \\
\text { Efricient }\end{array}$ & $\begin{array}{r}\text { Religerator } \\
\text { Efficient }\end{array}$ & $\begin{array}{r}\text { Neither } \\
\text { Efficicnt }\end{array}$ & 'l'otal \\
\hline Yes & 13 & 14 & 8 & 11 & 46 \\
Percent of Payments & $28 \%$ & $30 \%$ & $17 \%$ & $24 \%$ & $100 \%$ \\
No & 8 & 14 & 12 & 28 & 62 \\
\hline Total & 21 & 28 & 20 & 39 & 108 \\
Percent of Total & $19 \%$ & $26 \%$ & $19 \%$ & $36 \%$ &
\end{tabular}

It appears that lack of availability of efficient appliances was a major factor in this program result. Program staff approved some exceptions if builders supplied documentation of their efforts to acquired efficient models. In addition, appliances may have had incorrect or missing energy guide labels; in some cases, more that one model number appeared on the name plate; homeowners may have brought their own appliances with them, despite the builder's intentions; and site visits sometimes occurred before the appliances were installed, precluding on-site verification.

The difficulties we encountered in verifying appliance efficiency during analysis point to the need for more effective verification mechanisms. Programs operating without site visits face a serious challenge in verifying efficiency, which indicates the need for a rating system that provides more information than currently provided by the Energy Guide Labels.

\section{Housing Characteristics}

Because the number of houses with both efficient appliances was so small $(n=21)$, we analyzed most variables independently relative to DHW and refrigerators. When we broke out the RCDP-2 sample into the thre: main heat types, three zones, and presence of efficient DHW, some very small cell sizes resulted (Table 2.3). ${ }^{2}$ The largest sub-samples were Zone 1 baseboard or heat pump systems.

Table 2.3. RCDP Cycle 2 Sample Sizes

(Cases with One Year of Consumption Data/Site Visit Data/DHW Categorized)

\begin{tabular}{|c|c|c|c|c|c|c|c|}
\hline & Zone 1 & & Zonc 2 & & Zone 3 & & \\
\hline Efficient DHW & Yes & No & Yes & No & Yes & No & Totals \\
\hline Heal Type & & & & & & & \\
\hline Bascboard & 13 & 16 & 16 & 9 & . & 14 & 73 \\
\hline Heal Pump & 20 & 18 & 4 & 3 & 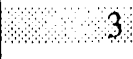 & 0 & 48 \\
\hline Furnace & 10 & 0 & 1.13 & 12 & & 2 & 8 \\
\hline Other & 0 & 2 & 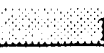 & 3 & 0 & $\Omega$ & 6 \\
\hline Totals & 33 & 36 & 2 & 17 & 9 & 16 & 135 \\
\hline
\end{tabular}

Note: Shaded cells denote small sample sizes $(\mathrm{n}<10)$

2 Cells with fewer than 10 cases are shaded in all tables. 
Overall, DHW-efficient houses were slightly smaller, had fewer occupants, and had smaller UA values and predicted space heat estimates. These relationships are roughly similar when the cases are separated into zones (Table 2.4). The finding that Zone 2 houses have higher predicted space heat than Zone 3 houses is due to the fact that Zone 3 homes were built to higher standards and had tighter, more thermally efficient shells. Among these housing characteristics, the only significant difference found was in the number of occupants. Because this is such an important determinant of hot water use, it confounded the analysis of savings from efficient water heaters.

Table 2.4, RCDP Cycle 2 Housing Characteristics All Heat Types

\begin{tabular}{|c|c|c|c|c|c|c|c|c|}
\hline the & Zone 1 & & Zone 2 & & Zone 3 & & All Zones & \\
\hline Efficient DHW & Yes & No & Yes & $\mathrm{No}$ & Yes & $\mathrm{No}$ & Yes & No \\
\hline Floor Area std dev & 1,668 & 1,736 & 1,957 & 2,323 & 2,650 & 2,625 & $\begin{array}{r}1,919 \\
522\end{array}$ & $\begin{array}{r}2,099 \\
742\end{array}$ \\
\hline $\begin{array}{r}\text { Overall UA (BTU/F) } \\
\text { std dev }\end{array}$ & 400 & 406 & 356 & 428 & $1 \% 350$ & 371 & $\begin{array}{r}376 \\
86\end{array}$ & $\begin{array}{l}403 \\
113\end{array}$ \\
\hline \begin{tabular}{|} 
Predicted \\
Space Ht (kWh/sf/yr) \\
std dev
\end{tabular} & 2.32 & 2.54 & 3.43 & 4.00 & $18.2 \%$ & 3.52 & $\begin{array}{l}2.87 \\
0.89\end{array}$ & $\begin{array}{l}3.14 \\
1.08\end{array}$ \\
\hline $\begin{array}{r}\text { Number of Occupants } \\
\text { std dev }\end{array}$ & 2.6 & $3.4 a, b$ & 3.3 & 3.4 & $1,3,0$ & 3.6 & $\begin{array}{l}2.9 \\
1.1\end{array}$ & $\begin{array}{l}3.4 \mathrm{a} \\
1.7\end{array}$ \\
\hline
\end{tabular}

Note:

$\mathrm{a}=$ ANOVA probability level $<.05$

$b=$ Wilcoxin Rank Sum probability level $<.05$ 


\section{APPLIANCE CHARACTERISTICS AND ELECTRIC USE}

\section{Paid Innovation}

Not unexpectedly, no significant differences were found between homes that had or had not been credited for having efficient appliances in total, space heat, DHW, refrigerator or "other".3 consumption (Table 3.1). DHW and refrigerator consumption was actually slightly higher in the "paid" group.

Table 3.1. Consumption vs. Paid Innovation

\begin{tabular}{|l|cr|}
\hline End Uses $(\mathrm{kWh})$ & \begin{tabular}{|ll} 
Paid Innovation \\
Yes
\end{tabular} & \multicolumn{1}{|c|}{ No } \\
\hline Total & 18,266 & 18,793 \\
Space Heal & 6,541 & 6,987 \\
DHW (per unit) & 4,488 & 4,117 \\
Refrigerator & 992 & 939 \\
"Other" (per unit) & 7,186 & 7,545 \\
\hline
\end{tabular}

There are two issues to consider in weighing these data. 'The first is that it is difficult to verify that efficient appliances have actually been installed. The second issue assumes that the builder or homeowner did install an efficient appliance, but not the one they would have installed in the absence of an incentive. It is probable that the incentive created an unintended consequence, since the contractor may have converted the additional appliance payment into an upgrade: a larger water heater or a larger refrigerator with more features. The available data on volumes of both appliances support this theory. Upgrades in features or size would cause an increase in consumption that might counteract higher efficicncies. The findings of this study are a counterpoint to recommendations that, in the absence of efficiency standards, rebates or incentives are an appropriate mechanism by which to acquire conservation resources (Geller, 1985).

\section{Refrigerators}

Efficient refrigerators were significantly larger than non-efficient models $(20.2 \mathrm{vs} .19 .2 \mathrm{cu} . \mathrm{ft}, \mathrm{p}<$ 0.05). Thirty-nine percent of efficient models were in the 20.5-22.4 cu.ft. range; the same fraction of the non-efficient units were in the 18.5-20.4 cu.ft. range. Five percent of efficient refrigerators were larger than $26.5 \mathrm{cu}$.ft.; none of the others were that large (Figure 1). Features such as automatic ice makers and through-the-door ice dispensing were also common among the larger "efficient" models.

3 "Other" consumption is calculated as total use minus space heat and DHW consumption. It is used as a crude surrogate for internal gains here. 
Figure 1: Refrigerator Volume By Efficiency class

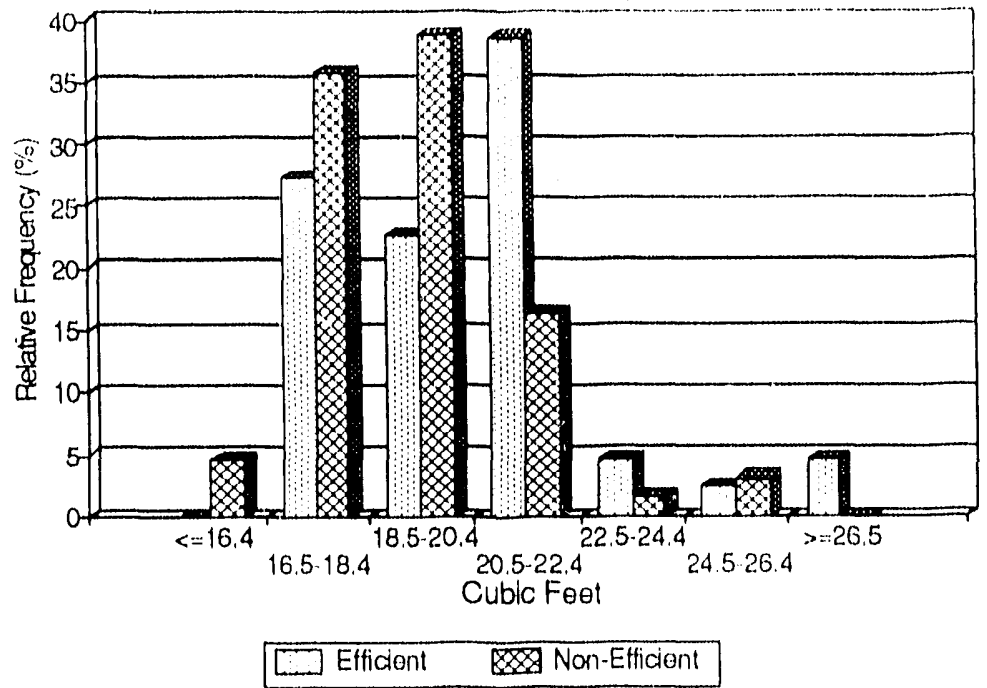

Based on Blue Clue specifications, a $26.5 \mathrm{cu}$.ft. side-by-side refrigerator with an ice dispenser would be considered efficient if its Energy Guide Cost did not exceed $\$ 1$ ()2. By comparison, all 18 cu.ft. top-freezer refrigerator with only automatic defrost would not be considered efficient if its Energy Guide Cost exceeded \$59. The results found in the RCDP-2 homes make questionable the use of a marketing program (such as Blue Clue) coupled with incentive payments, in order to acquire efficiency.

Furthermore, the RCDP-2 homes were built and outfitted at a time when appliance standiards were changing. The 1993 federal standards represent a significant improvement over what was typically installed in 1987. However, at the time, the top 1.5 percent of refrigerators were not that different from others available. There was a significant overlap between the expected costs of the two groups: more refrigerators in the efficient group had EG costs below $\$ 6()$ than in the non-efficient group, but both groups had similar expected cost distributicas that were skewed toward high cost models (Figures 2 and 3 ). Often, the difference between refrigerators considered efficient and similar units rated non-efficient was less than 5() $\mathrm{kWh} /$ year, or about $\$ 3 /$ year.

Figures 2 and 3: Predicted Annual Refrigerator Cost by Lfficiency Class
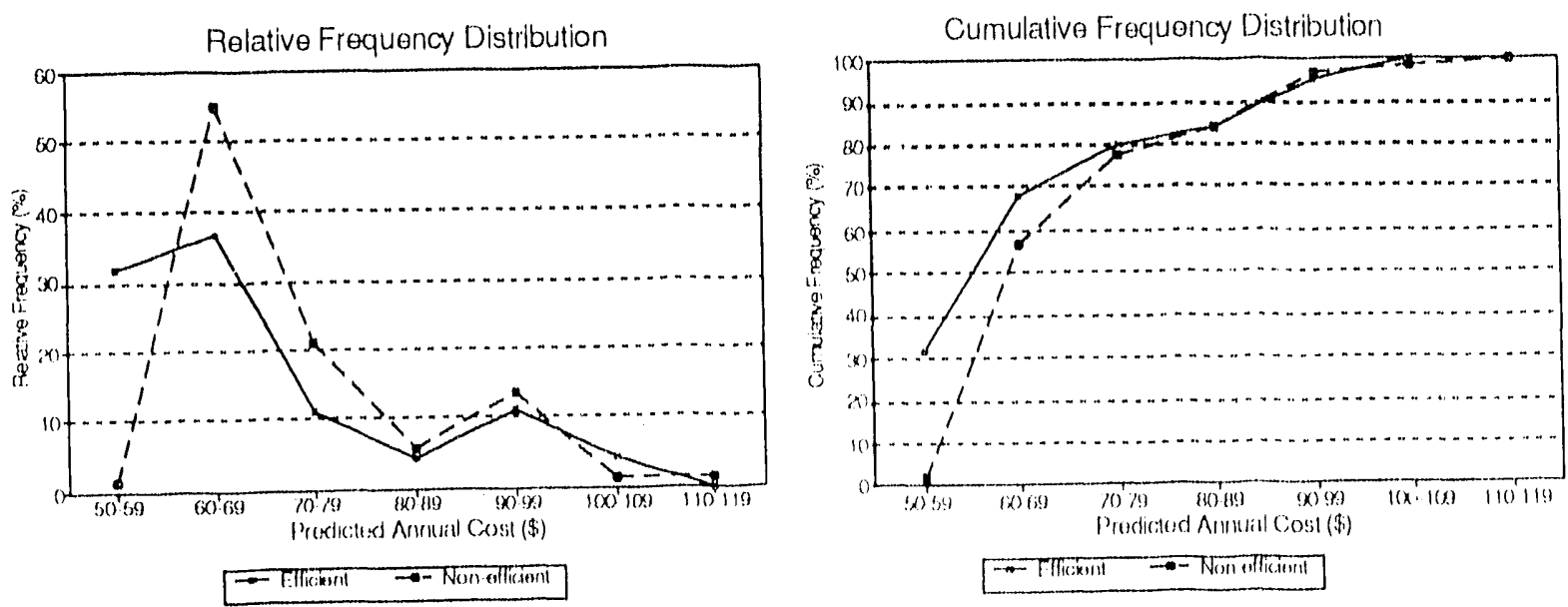
Refrigerator consumption levels were very similar between the two groups (Table 3.2). Based on the Energy Guide Costs, we would not expect to find differenees. Both types of refrigerators performed better than expected. The average predicted use was $1,() 28 \mathrm{kWh}$ for efficient units and $1,079 \mathrm{kWh}$ for non-efficient. The actual use was 92.5 and $8.54 \mathrm{kWh}$, respectively. Actual use averaged 95 percent of predicted use across all zones, based on a linear regression model. The correlation coefficient between estimates and measured dala was $(0.57(p<.(0)(0) 1)$.

Table 3.2. Refrigerator Characteristics and Consumption

\begin{tabular}{|l|rr|rr|}
\hline Efficient Refrigerator & \multicolumn{1}{|c|}{ Yes } & Std.Dev, & \multicolumn{1}{c|}{ No } & Std.Dev, \\
\hline Volume (cu.ft.) & 20.2 & 2.5 & 19.2 & 2.0 \\
Consumption (kWh) & 925 & 391 & 886 & 236 \\
Consumption/unit (kWh) & 925 & 391 & 854 & 247 \\
Predicted Consumption (kWh) & 1,028 & 209 & 1,079 & 170 \\
Consumption/cu.ft. & 46.0 & 18.6 & 44.6 & 12.3 \\
\hline
\end{tabular}

Notes:

$a=A N O V A$ probability level $<.05$

$b=$ Wilcoxin Rank Sum probability level<.05

The fact that actual performance exceeded predicted performance is not surprising, considering how the predicted use is calculated by the U.S. Department of Energy: empty refrigerators are kept in sealed room's at 900F for one day. The daily $\mathrm{kWh}$ consumption is then multiplied by 365 for the annual consumption. Recent research (Nelson and Short, 1990) has shown a strong correlation between outside temperature and refrigerator consumption in cooling months. Most of the RCDP-2 homes are built in climates with mild summers. But, even during the warmest months, these homes have shells tight enough to degrade the relationship between outside temperature and refrigerator use.

\section{Water Heaters}

In contrast to refrigerators, water heater efficiency was determined simply--by the single criterion of energy factor (EF). The median energy factors were 0.94 and 0.88 in the two groups. The efficient models clustered around the RCDP-2 EF requirement (0.93), while the nonefficient models clustered around the 0.88 level--the legal minimum in Washington at the time. Exhaust air heat pump water heaters, which have an EF of 3.1 , represent 12 percent of the efficient group. The first hour ratings for the two groups were similar (61 vs. 59). The measured delivery water temperature was consistent in Zones 1 and 2--between 122 and 127 degrees Fahrenheit; higher tap temperatures (135 degrees) were observed in Zone 3 (Table 3.3).

The efficient water heaters were slightly larger than the non-efficient (.57 vs. 54 gallons; $p<.(05)$. The majority of efficient models (62 percent) had 52 gallon capacities, while the same proportion (60 percent) of less than efficient models had $5($ )-gallon capacities (Figure 4$)$. The efficient group had a larger proportion of 80 to 82 gallon tanks (14 percent vs. 5 percent) and a smaller proportion of 62 to 66 gallon tanks (9 percent vs. 14 percent). A chi-square test on partially collapsed categories was not significant. 
Table 3.3. DHW Characteristics and Consumption

\begin{tabular}{|c|c|c|c|c|c|c|c|c|c|}
\hline \multirow[b]{2}{*}{ Efficient $\overline{\mathrm{DHW}}$} & \multicolumn{2}{|l|}{ Zone 1} & \multicolumn{2}{|l|}{ Zone 2} & \multicolumn{2}{|l|}{ Zone 3} & \multicolumn{3}{|l|}{ Total } \\
\hline & $Y e s$ & No & Yes & No & Yes & No & Yes & No & \\
\hline Energy Factor (Mcdian) & 0.94 & $0.89 a, b$ & 0.94 & 0.88 & 0.96 & $0.84 a, b$ & 0.94 & $(0.88$ & $a, b$ \\
\hline $\begin{array}{l}\text { Volume (gallons) } \\
\text { std dev }\end{array}$ & 55 & $54 \quad \mathrm{~b}$ & 55 & 56 & 19.67 & $51 \mathrm{a}, \mathrm{b}$ & $\begin{array}{l}57 \\
10\end{array}$ & $\begin{array}{r}54 \\
8\end{array}$ & $\mathrm{~b}$ \\
\hline 1st Hour Rating & 60 & 60 & 60 & 61 & 68 & 57 & $\begin{array}{r}61 \\
6\end{array}$ & $\begin{array}{r}59 \\
7\end{array}$ & \\
\hline $\begin{array}{r}\text { Tap Temp (Degrees F) } \\
\text { std dev }\end{array}$ & 125 & 127 & 122 & 122 & 135 & 135 & $\begin{array}{r}126 \\
11\end{array}$ & $\begin{array}{r}128 \\
14\end{array}$ & \\
\hline Inside Heated Space (\%) & $52 \%$ & $41 \%$ & $100 \%$ & $100 \%$ & $18.88 \%$ & $81 \%$ & $75 \%$ & $65 \%$ & \\
\hline $\begin{array}{r}\text { Consumption (kWh) } \\
\text { std dev }\end{array}$ & 3,755 & 4,530 & 4,542 & 4,815 & 3,468 & 4,854 & $\begin{array}{l}4,002 \\
1,646\end{array}$ & $\begin{array}{l}4,675 \\
2,127\end{array}$ & a \\
\hline $\begin{array}{l}\text { Consumption/Occupant(c) } \\
\text { Consumption/Occupant(d) }\end{array}$ & $\begin{array}{l}1,562 \\
1,444\end{array}$ & $\begin{array}{l}1,592 \\
1,332\end{array}$ & $\begin{array}{l}1,564 \\
1,376\end{array}$ & $\begin{array}{l}1,555 \\
1,416\end{array}$ & 1.255 & $\begin{array}{l}1,715 \\
1,348 \\
\end{array}$ & $\begin{array}{l}1,519 \\
1,380 \\
\end{array}$ & $\begin{array}{l}1,610 \\
1,375\end{array}$ & \\
\hline
\end{tabular}

Note:

$a=A N O V A$ probability levei<. 05

$b=$ Wilcoxin Rank Sum probability level<.05

$c=$ Average of ratios

$d=$ Ratio of averages

Figure 4: DHW Volume By Efficiency Class

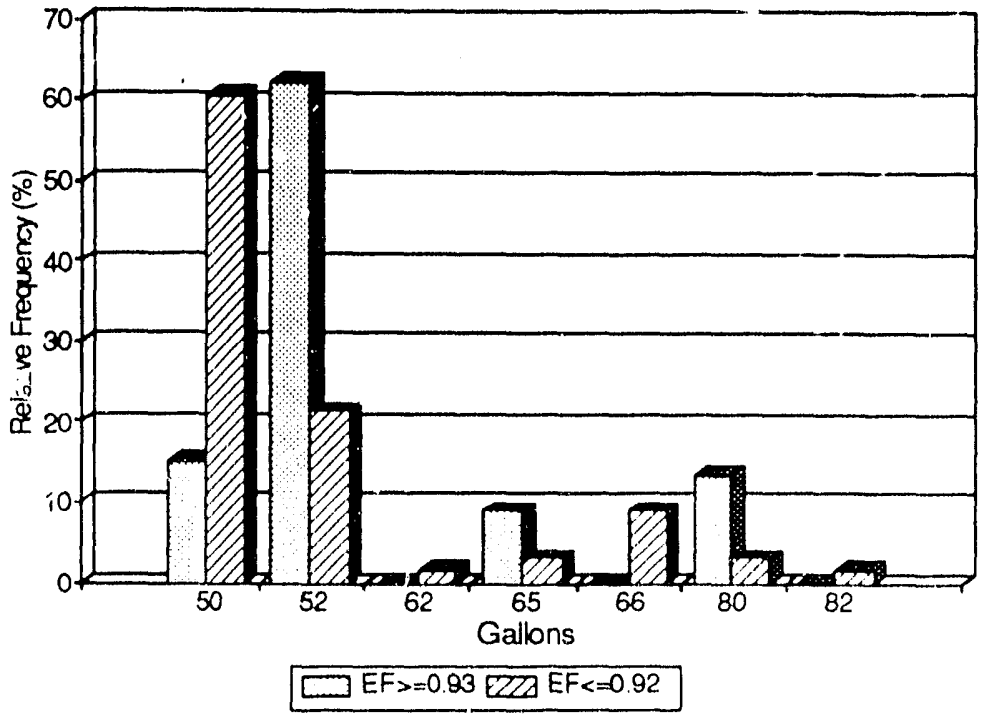


Overall, the efficient water heaters used $673 \mathrm{kWh}$ less than the non-efficient models $(\mathrm{p}<.05)$. Normalizing by tank size did not enhance the explanatory power of the data. The sample sizes for the larger tanks were small and their consumption, in both efficiency groups, fell almost exactly half-way between the consumption of efficient and non-efficient tanks in the 50 to 52 gallon size range (Figure 5).

Figure 5: DHW Consumption: Zone 1 By Tank Size

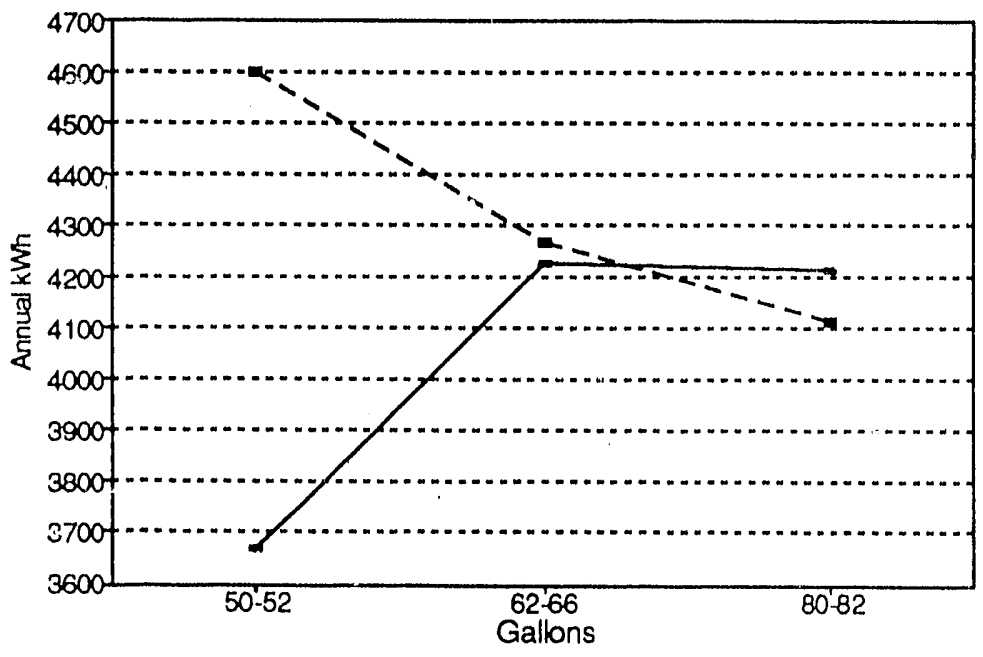

$E F>0.93 \rightarrow-E F<0.92$ 
We did find, however, that number of occupants correlated very well with consumption (rho $=0.43, \mathrm{p}<.00(01 ;$ Figure 6 ). Unfortunately, the efficient group had significantly fewer occupants (2.9 vs. $3.4, p<.05)$, which confounded the savings analysis. Figure 7 and Table 3.4 show consumption as a function of EF and number of occupants. While there is a downward trend in consumption as EF increases, this is confounded by occupancy differences. When corrected for number of occupants, consumption in the EF range of 0.85 to 0.95 is fairly flat.
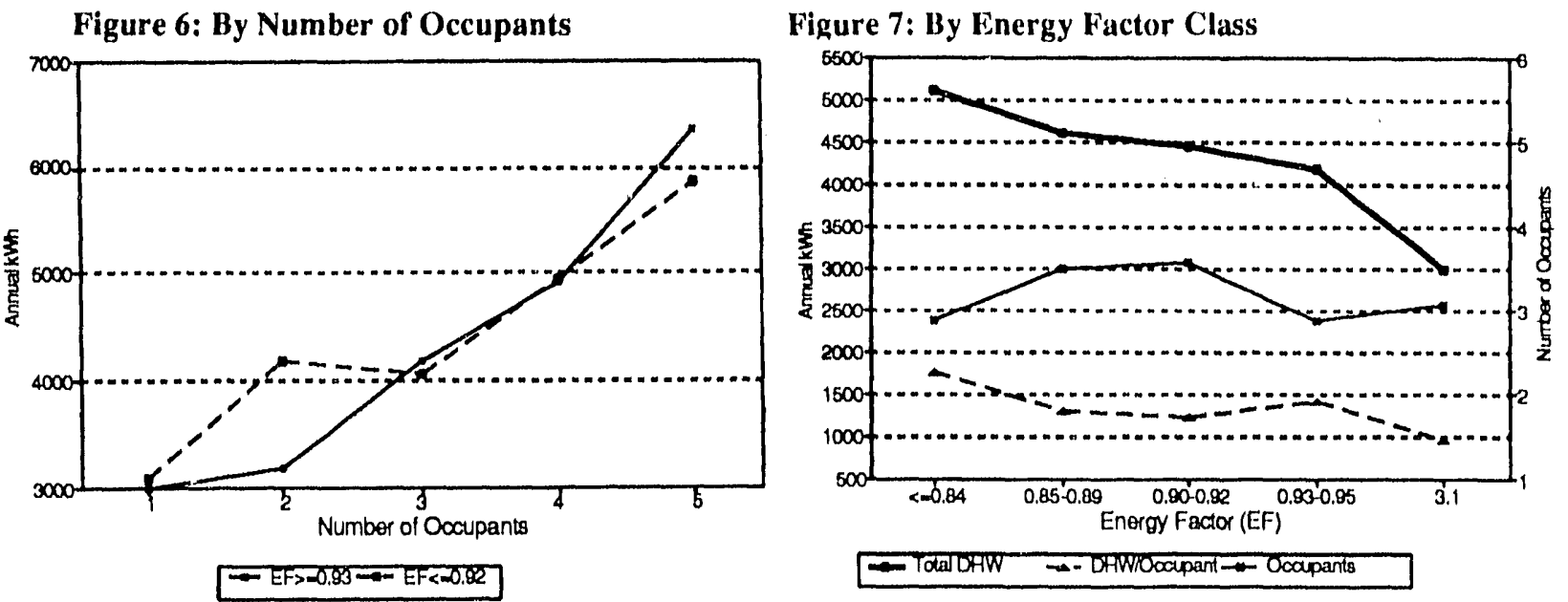

Table 3.4. DHW Consumption by Energy Factor Class

\begin{tabular}{|c|c|c|c|c|c|c|}
\hline Energy Factor & Zone 1 & Zone 2 & Zone 3 & $\begin{array}{c}\text { All Zones } \\
\mathrm{kWh}\end{array}$ & Occupants & $\begin{array}{c}\mathrm{kWh} / \\
\text { Occupant }\end{array}$ \\
\hline$<=0.84$ & .8594 & 4598 & 9008 & 5134 & 2.9 & 1770 \\
\hline $0.85-0.89$ & 4408 & 4985 & 4745 & 4621 & 3.5 & 1320 \\
\hline $0.90-0.92$ & 4638 & 4456 & & 4475 & 3.6 & 1243 \\
\hline $0.93-0.95$ & 3798 & 4804 & $410 \%$ & 4197 & 2.9 & 1447 \\
\hline 3.1 & 3094 & 2100 & 3228 & 3000 & 31 & 968. \\
\hline
\end{tabular}

When broken down by zone, the data trends become less stable because of small cell sizes (Figure 8). Unfortunately, we did not have enough cases to disaggregate by zone, EF, and number of occupants, and still maintain data reliability.

Figure 8: DHW Consumption By Energy Factor Class and Zone

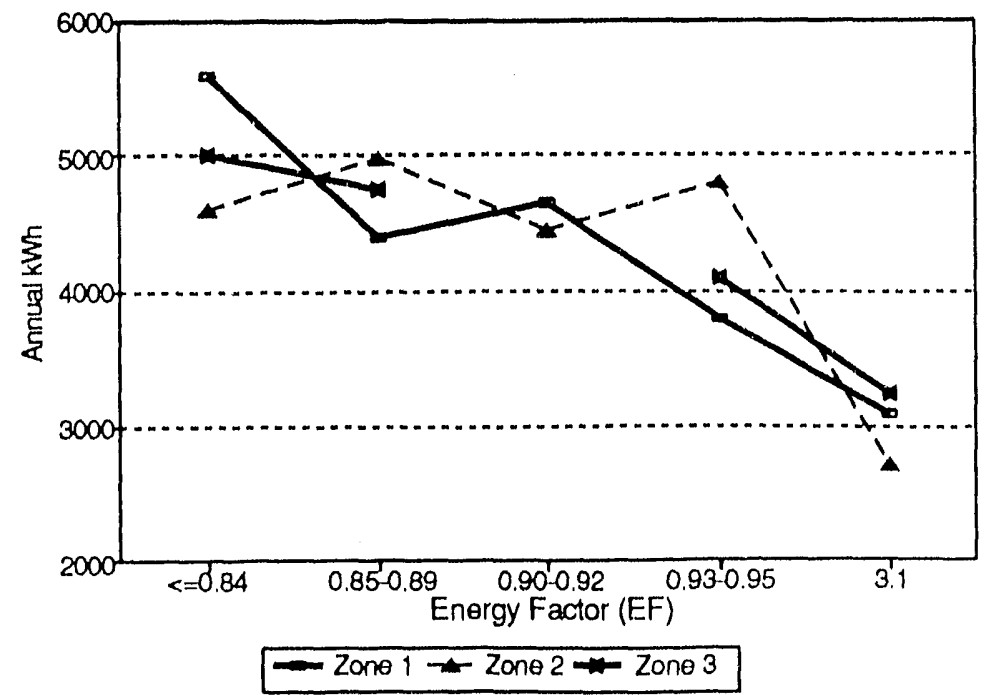




\section{Exhaust Air Heat Pump Walter Heaters}

The exhaust air heat pump (EAIP) water heaters performed much better than conventional types, when corrected for number of occupants or climate zone. A stritightforward eomparison of EAHP systems with conventional systems is complicatted by the fact that these watce heallers also produced some supplementary space heating. Furthermore, the energy used for space heating cannot be separated analytically from energy used for water heating. Based on the measured performance of these DHW systems, we can infer that they are very efficient, since only a fraction (which is undetermined) of their energy consumption was devoted to heating water. Conversely, the energy used for space heating in heat pump heating systems is underestimated, as it does not account for space heating provided by the water heater.

\section{Multiple Regression}

With multiple regression andlysis we attempted to tease out the relative importance of several factors that affect DHW consumption. Multiple regression analysis determines the variance in the dependent $:$ ariable (DHW consumption) that can be accounted for by a series of independent variables. Factors that play a role in DHW consumption include number of occupants, energy factor (in five classes), delivery temperature of hot water, and location of the water heater (a dummy variable for location inside heated space). ${ }^{4}$ In order to control for weather effects, we isolated Zone 1 cases, which had the largest sample sizes. The only variable that was significant in the regression was number of occupants (Table 3.5).

Table 3.5. Regression Parameters for DHW Consumption (Maximum R-Square Improvement Method)

Dependent Variable $=$ DHW Consumption $(\mathrm{kWh})$

\begin{tabular}{|c|c|c|c|c|c|}
\hline $\begin{array}{l}\text { Variable } \\
\text { Entered }\end{array}$ & $\begin{array}{c}\text { Step } \\
\text { Entered }\end{array}$ & $\begin{array}{l}\text { Final Value } \\
\text { Coefficient }\end{array}$ & $\begin{array}{c}\text { Final } \\
\mathrm{F}\end{array}$ & $\begin{array}{c}\text { Probability } \\
>\mathrm{F}\end{array}$ & $\begin{array}{l}\text { R-Squared } \\
\text { al Entry Step }\end{array}$ \\
\hline Intercept & 1 & -1001 & 0.15 & 0.70 & \\
\hline Occupants & 1 & 930 & 30.29 & $0.0(0) 1$ & 0.426 \\
\hline DHW Temperature & 2 & 25 & 1.69 & $(0.20$ & 0.456 \\
\hline $\mathrm{EF}$ (in 5 classes) & 3 & -247 & 1.19 & 0.28 & 0.470 \\
\hline DHW Location (inside $=1$ ) & 4 & 188 & 0.18 & 0,68 & 0.472 \\
\hline
\end{tabular}

\section{Notes:}

1) Regression was done for Zone 1 homes only $(n=49)$.

2) No significant collinearity was detected in this set of variables.

4 We did not include tank size in the regression because the earlier exploratory analysis indicated that volume would be a poor predictor of consumption. 
Monthly Use and End Use Lond Factors

Profiles of monthly consumption by climalle zone and DollW efficiency girtup ant shown in Figgures 9 through 11 (data are in the $A p p e n d i x$ ). Agaim, als a caveall, this amalysis is contomonded by occupancy differences. When aggregated across zones, lwo trends secon evident. Fitrst, absolute energy savings are similar at both minimum and maximum comsumption points, implying that both energy and peak savings accrue o efficient water heaters. Second, the consumption curves have roughly the same shape, except that the curve of efficient cases hats a broader period of minimum use and a slightly steeper slope in shoulder months (Spring and Fall; Figure 12). This implies that periods of high energy loss from the DHW tanks is shorter in the efficient group.

Monthly DHW Consumption:

Figure 9: Zone 1

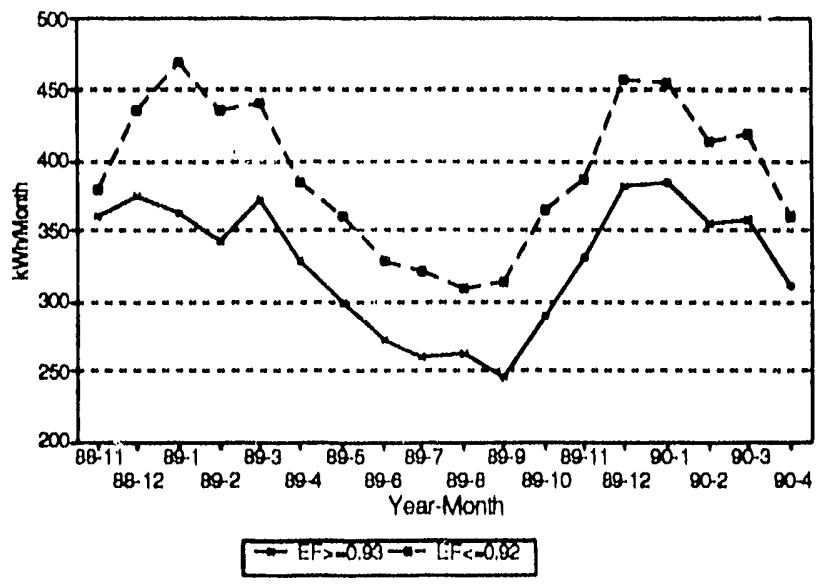

Figure 11: Zone 3

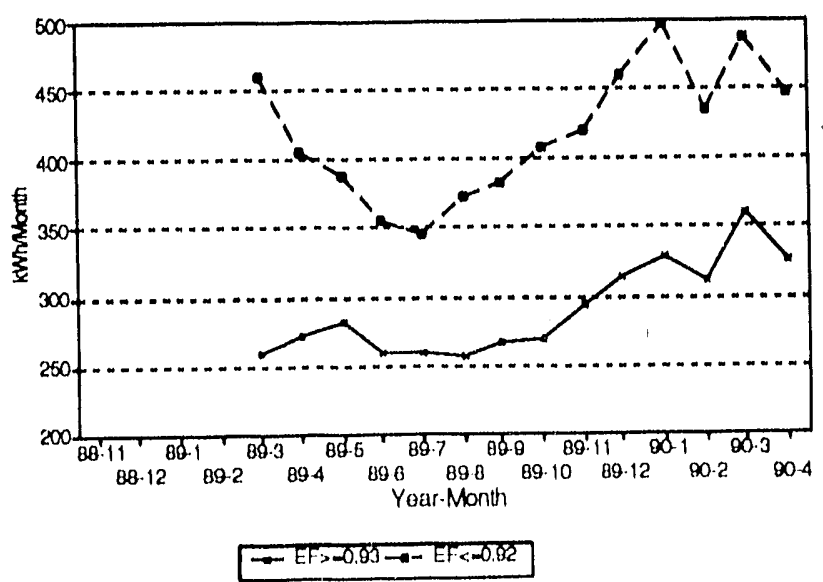

Figure 10: Zone 2

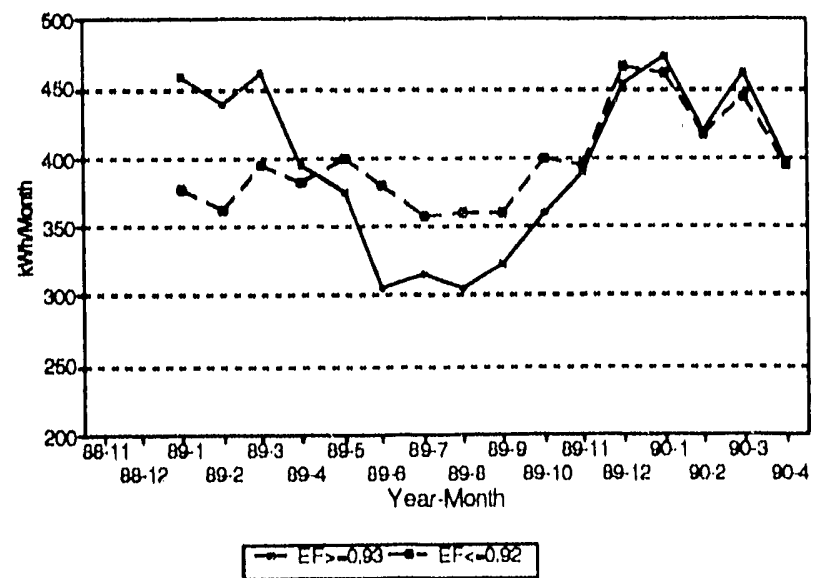

Figure 12: All Zones

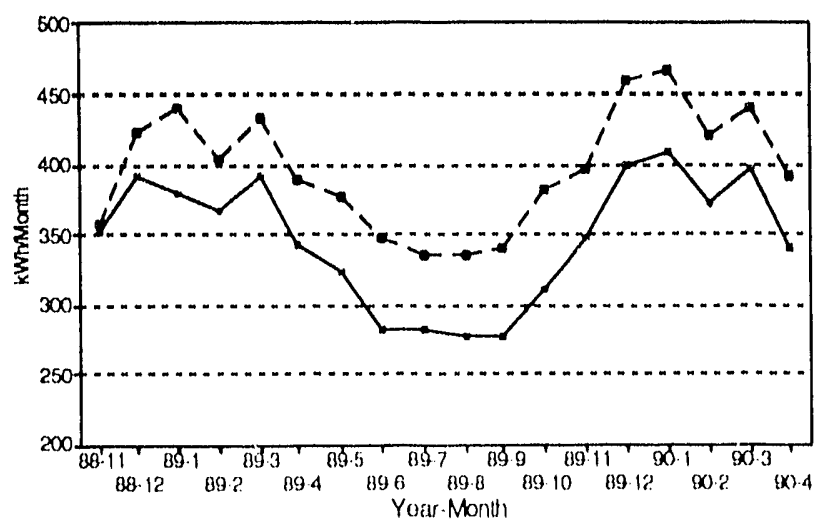

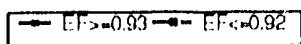

In an end use load factor analysis, we computed ratios of average-to-peak use. 5 Over all climale zones, the efficient water heaters have a slightly lower load factor than the non-efficient appliances (82 percent vs. 84 pereent). In Zone 1 (which has the largest cell sizes), there is no

5 Previous work on load factors has used hourly data, which is a much stronger measure of peak demand. The use of monthly data weakens the analysis, but still provides useful information. 
difference between groups: both have load factors of 82 percent, and savings in peak use appear stable. Relative to system needs, it seems that no additional incremental peak loads result from efficient water heaters. The advantage of improved water heater efficiency does not introduce the same problem that was encountered in the Hood River Project, where shell efficiency gains led to lower load factors and relative increases in peak demand (Stovall, 1987). As such, efficient water heaters may mitigate problems related to lower load factors introduced by standard shell improvement programs, and could serve well as tandem measures. 


\section{DHW/SPACE HEAT INTERACTION EFFEC:IS}

\section{RCDP-2 Empirical Results}

Space Heat

The waste heat from an appliance in a conditioned space reduces the heating load of the home. If an efficient appliance is introduced to the space, it will use less energy, but will also produce less waste heat. This causes the heating system to l:se more energy to maintain the temperature in the home. Thus, the net energy savings from the appliance is the energy savings from increased efficiency minus the additional heating required to maintain space temperature.

Dent (1991) analyzed heating system performance in Northwest homes (including the RCDP-2 homes) and found that space heat in the RCDP-2 group was higher when DHW tanks were inside the heated space than when they were outside. This contrasted with Super Good Cents homes, which showed the opposite (and expected) relationship of DHW placement and space heat. Dent attributed these results to interaction effects between climate zone, building shell efficiency, and the presence of a basement in some homes.

In order to assess the impacts on space heating from efficient water healers, we isolated cases where the appliance was inside the heated space. Unfortunately, this led to very small cell sizes. Overall, there were no significant differences in space heat use per square foot (calculated for 9 months, from September through May; Table 4.1).

Table 4.1. Space Heat Consumption Per Square Foot (kWh/sq.ft/9-mos.) (Where DHW Located Inside Heated Space)

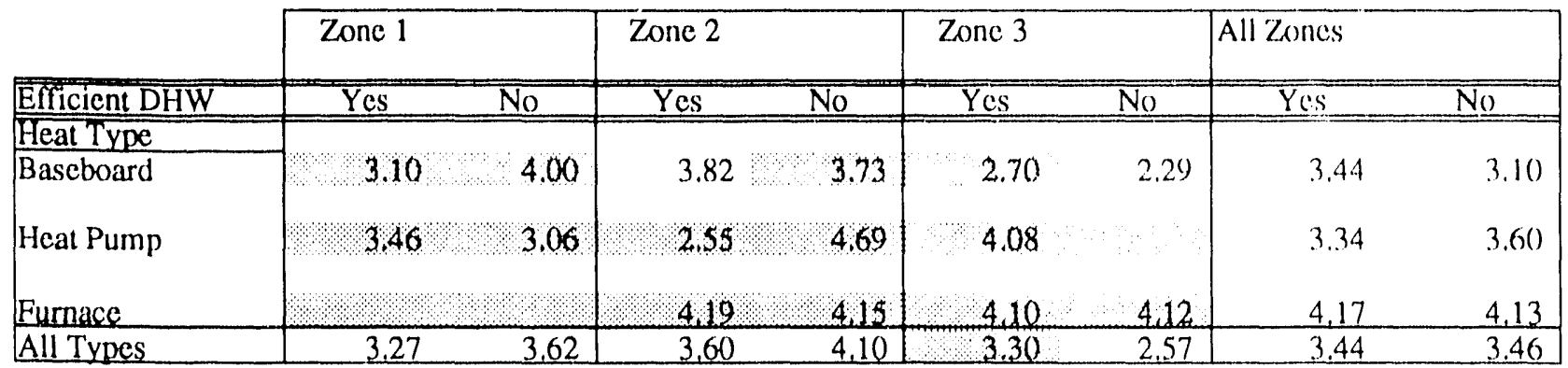

Based on thermodynamic theory, we would expect that efficient appliances would lead to increased space heating needs. The paucity of data preclude any empirical finding, however. In addition, the situation is complicated by the fact that DHW-efficient homes also have 11 percent lower "other" consumption than the comparison group. This surrogate for internal gains ${ }^{6}$ would have an impact on space heating needs as well: lower consumption of lighting and appliances would create more demand for space heating.

\section{End Use Consumption Totals}

The proportions of energy going to various end uses is quite similar between the two groups (Table 4.2; Figures 13 and 14). Space heat accounts for 38 percent of total annual use in the efficient group, compared to 36 percent in the other group. DHW use is 23 and 24 percent, respectively.

6 Because these data have not been screened for large external loads, like flood lights, shops, block heaters or swimming pools, they must be viewed as preliminary. 
Table 4.2. End Use Consumption by DHW Efficiency (iroup:

Other=|'Total - (DHW + Space) | Total=Utility Meter

\begin{tabular}{|c|c|c|c|c|c|c|c|c|c|}
\hline \multirow{2}{*}{ Efficient DHW } & \multicolumn{2}{|l|}{ Zone 1} & \multicolumn{2}{|l|}{ Lone 2} & \multicolumn{2}{|l|}{ Lone 3} & \multicolumn{3}{|l|}{ T'otal } \\
\hline & Yes & No & Yes & No & $\overline{Y c s}$ & No & Yes & No & \\
\hline DHW $\quad$ std dev & 3,755 & 4,530 & 4,542 & 4,815 & 3,468 & 4,854 & $\begin{array}{l}4,002 \\
1,646\end{array}$ & $\begin{array}{l}4,675 \\
2,127\end{array}$ & a \\
\hline $\begin{array}{l}\text { Space Heal } \\
\text { std dev }\end{array}$ & 5,785 & 5,957 & 7,236 & 9,534 & $8,8,120$ & 6,386 & $\begin{array}{l}6,631 \\
3,020\end{array}$ & $\begin{array}{l}6,938 \\
4,678\end{array}$ & \\
\hline stud dev & 6,838 & 7,383 & 7,049 & 8,260 & 1,314 & 8,584 & $\begin{array}{l}6,980 \\
2,657\end{array}$ & $\begin{array}{l}7,878 \\
4,047\end{array}$ & \\
\hline T'otal & 16,379 & 17,870 & 18,827 & 22,609 & 18,902 & 19,824 & 17,613 & 19,491 & \\
\hline
\end{tabular}

Note:

$a=A N O V A$ probability level<.05

Figure 13: DHW/Space Heat/Other

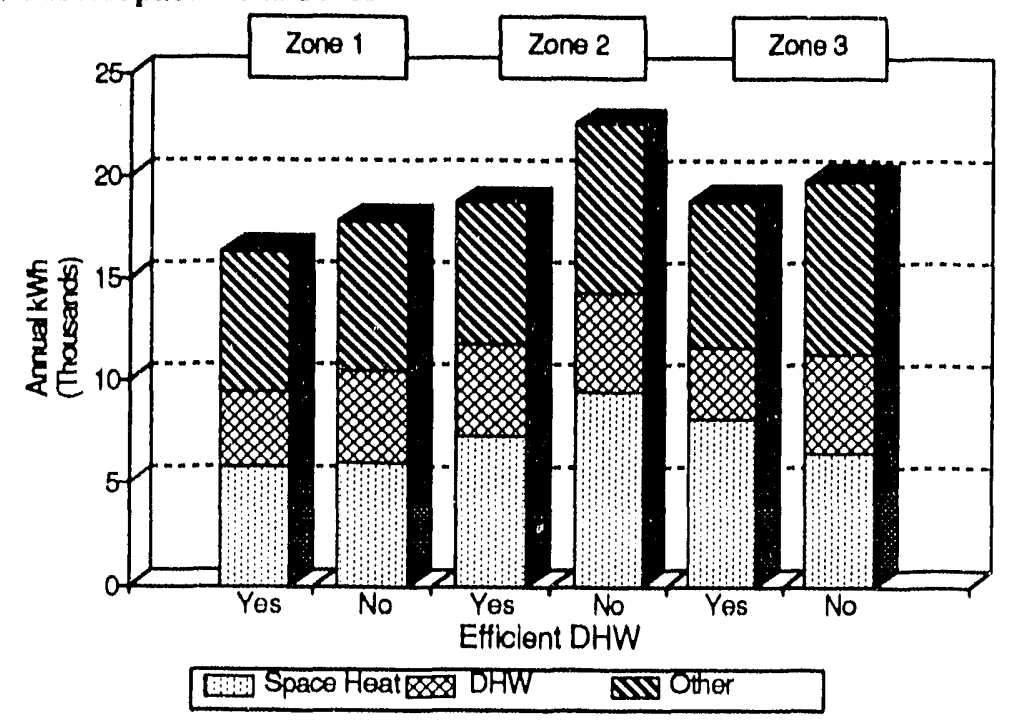

Figure 14: DHW Energy Factor $>0.93$

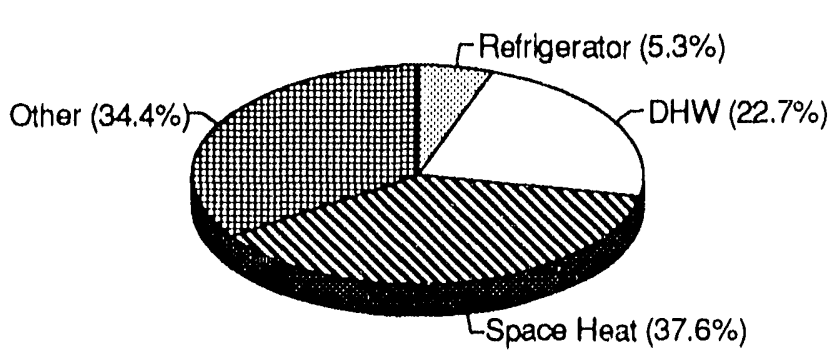

DHW Energy Factor $<0.92$

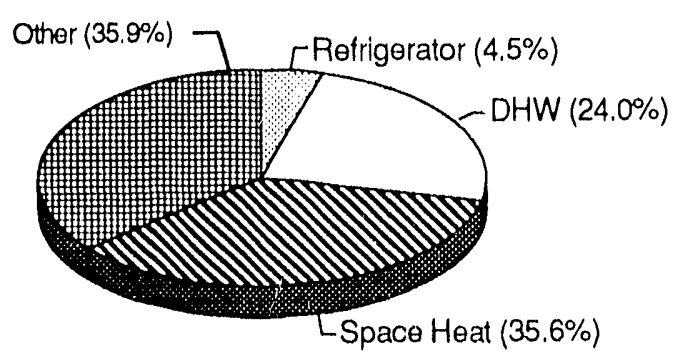


Multiple Regression

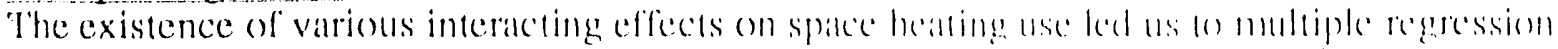

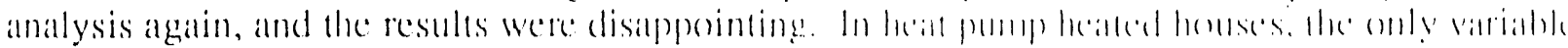

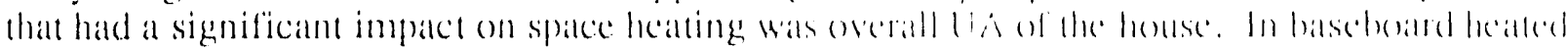

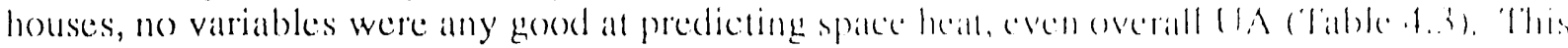

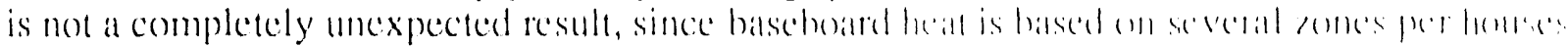
while heat pumps are whole-house systems.

Table 4.3. Regression Parameters for Space Heat Consumption (Maximum R-Square Improvement Method)

Zone 1: Heat Pump Leating System

Dependent Variable = Space Heat Consumption (kWh)

\begin{tabular}{|c|c|c|c|c|c|}
\hline $\begin{array}{l}\text { Variable } \\
\text { Entered }\end{array}$ & $\begin{array}{c}\text { Step } \\
\text { Entered }\end{array}$ & $\begin{array}{l}\text { Final Value } \\
\text { coefficient }\end{array}$ & Final & $\begin{array}{c}\text { Probabilily } \\
\geq V\end{array}$ & $\begin{array}{l}\text { R-Squared } \\
\text { al Entry'sicels }\end{array}$ \\
\hline Intercept & 1 & -482 & 0.0 & 0.90 & \\
\hline Ua & 1 & 19,4 & 9.5 & 0.0015 & ().28.5 \\
\hline EF (in 5 classes) & 2 & -259 & $(0.3$ & 0.00 & 0.301 \\
\hline DHW Consumption (kWh) & 3 & $-(0.3$ & ().7 & 0.4() & 0.308 \\
\hline DHW Locaulion (inside $=1$ ) & 4 & 173 & 0.0 & 0.87 & $(1,300)$ \\
\hline
\end{tabular}

Notes:

1) No significant collinearity was detected in this set of variables.

Zone 1: Baseboard Heating System

Dependent Variable = Space Heat Consumption ( $\mathrm{kWh}$ )

\begin{tabular}{|c|c|c|c|c|c|}
\hline $\begin{array}{l}\text { Variable } \\
\text { Entered }\end{array}$ & $\begin{array}{c}\text { Step } \\
\text { Entered }\end{array}$ & $\begin{array}{l}\text { Final Value } \\
\text { Coefficient }\end{array}$ & $\begin{array}{l}\text { Final } \\
F:\end{array}$ & $\begin{array}{c}\text { Probability } \\
>\mathrm{F}\end{array}$ & $\begin{array}{l}\text { R-Squarel } \\
\text { at Entry Step }\end{array}$ \\
\hline Intercept & 0 & 2816 & 0.7 & 0.40 & \\
\hline UA & 2 & 5.1 & 0.7 & 0.41 & 0.083 \\
\hline DHW Consumption (kWh) & 1,4 & -0.2 & 0.3 & 0.58 & 0.098 \\
\hline $\mathrm{EF}$ (in 5 classes) & 5 & 261 & 0.3 & ().59 & 0.098 \\
\hline DHW Location (inside $=1$ ) & 3,6 & 556 & 0.3 & 0.59 & 0.111 \\
\hline
\end{tabular}

\section{Notes:}

1) No significant collinearity was detected in this set of variables.

\section{Modeling of Space Heat Interactions}

Because we could not find the relationships predicted by thermodynamics in the RCDP-2 datit, we performed an analysis using the DOE-2 Building Energy Simulation Program to estimate the net energy savings from efficient appliances. DOE-2 is an hourly energy simulation program that calculates the heating load for a given set of conditions and for a variety of heating systems, including zonal or central types. The model can divide the building into zones, which permits examination of the dynamic interactions between space heal and appliances in specific areas within the building. Inputs for the DOE-2 model include house, heating, and appliance characteristics.

\section{Model Description}

The house model used in this analysis is intended to be a typical residence operating under a sut of typical conditions. In this analysis, we used one prototype home from a study performed for the Washington Legislature (Byers, 1989). This prototype home is similar to one used by the Northwest Power Planning Council in its analyses. The model assumptions are as follows: 
Residence: $\quad$ Prototype 1, 1.344 scyuare foot rambler (Figure in Appendix).

Location: Zone 1, Portland weather data.

HVAC Type: A zoned electric baseboard and a central heall pump system are modeled. No air conditioning is modeled.

Occupancy: Three residents. The house is not occupied during the day on weekdays-.. residents are assumea to be at school or work.

Zoning: Three conditioned zones are modeled: kitchen/living room, master bedroom/bath, and 2 bedrooms/bath/hall. Three unconditioned zones are modeled: garage, attic, and crawl space.

Thermostats: The thermostat is located in the hall for the heat pump system (bedroom/bath/hall zone) and there is a thermostat in each conditioned zone for the baseboard system.

Setpoint: $\quad$ The home is modeled with a $70^{\circ}$ Fahrenheit occupied setpoint and an 8 hour, $62^{\circ} \mathrm{F}$ night time setback.

Infiltration: This is assumed to be a tightly constructed house with low levels of natural ventilation. An effective mechanical ventilation system maintains a total infiltration/ventilation level of 0.35 air changes per hour $(\mathrm{ACH})$. Infiltration is set at a constant 0.35 air changes per hour in the model. The model schedules higher evening and night time infiltration levels in the summer to account for open windows. This does not effect heating, but helps avoid reaching excessive summer indoor temperatures.

Envelope: The envelope meets MCS requirements.

Windows: $\quad$ Windows are located as indicated on plans for prototype 1 (see Appendix). The residence is modeled with two orientations to cover the extreme conditions the living room/kitchen side facing south and north.

Appliances: $\quad$ Appliance use schedules are derived from ELCAP data (Pratt, et.al. 1989) The schedules apply to the zones in which the appliances are located, and account for seasonal variation. ELCAP average end-use load data are modified to show the peaky characteristics typical in occupied homes. The base case water heater and refrigerator correspond to the base case used by the Northwest Power Planning Council in their 1991 draft power plan (4434 kWh/yr and 947 kWh/yr, respectively; Northwest Power Planning Council, 199()). These values correspond to the RCDP data used in our analysis $(4,675$ $\mathrm{kWh} / \mathrm{yr}$ and $886 \mathrm{kWh} / \mathrm{yr}$, respectively, for appliances not rated efficient). The NPPC proposed efficient water heater incorporates features that reduce standby losses by $305 \mathrm{kWh} / \mathrm{yr}$ compared to the base case; the proposed efficient refrigerator will save $310 \mathrm{kWh} / \mathrm{yr} .7$ The water heater is modeled in both unheated space (garage) and in heated space (kitchen/living room zone).

7 Other measures targeting water end uses could save another $688 \mathrm{kWh} /$ year: low-flow showerheads, efficient clothes washers, and dishwashers. These potential savings are not included in this analysis. 
Model Targets and Results

The house model was tuned so that its major end-use energy consumption wals consistent with measured data of typical household use. Table 4.4 compares modeled energy' consumption with measured data targets.

Table 4.4. End Use Model Results and Targets

$\begin{array}{lll}\text { End-Use } & \text { Model } & \text { Target (Mcasured Data) } \\ \begin{array}{ll}\text { Heating } \\ \text { Baseboard }\end{array} & 4712 \text { (ELCAP:1350 } \mathrm{ft}^{2} \text { MCS Home) } \\ \text { Heat Pump } & 4495 & \\ \text { Hot Water } & 3402 & 4434 \text { (NWPPC Bascline) } \\ \text { Other } & 4430 & 6317 \text { (ELCAP:1350 ft }{ }^{2} \text { MCS Homc) }\end{array}$

Note: Other includes lighting, houschold appliances, and other plug loads.

Since hot water, lighting, and equipment use are directly scheduled into the DOE-2 model, it is not surprising that modeled and targeted use are essentially identical. Heating energy use for the baseboard case is slightly less than the ELCAP target. Modeled use is $3.34 \mathrm{kWh} / \mathrm{ft}^{2}$. This is consistent with other sources of data. An analysis of heating system performance in 472 homes built to MCS requirements--including $150 \mathrm{RCDP}-2$ houses--showed a use level of $3.12 \mathrm{kWh} / \mathrm{ft}^{2}$ for zonal systems in climate zone 1 (Dent, 1991). The heat pump uses $2.53 \mathrm{kWh} / \mathrm{ft} 2$ and shows a seasonal coefficient of performance (COP) of 1.3 relative to the baseboard system. This is somewhat better than the $2.93 \mathrm{kWh} / \mathrm{ft}^{2}(1.05 \mathrm{COP})$ shown by Dent. In the model, we reduced the efficiency of the heat pump from its default value by about one-third to account for system and distribution losses (ASHRAE, 1988). This moved the heat pump performance closer to the results shown in the measured data. However, a further reduction in modeled efficiency to get a closer match with measured data did not seem warranted without a better understanding of why the measured heat pump performance was so low.

\section{Estimated Net Appliance Energy Savings}

The DOE-2 model estimated the increase in space heat required when efficient water heaters and refrigerators were present in the prototype house, compared to a house with base case appliances. Net appliance energy savings were calculated by subtracting this increase in space heat energy use from the gross savings. The space heat interaction is the percentage of gross savings from an efficient appliance that must be made up by additional space heating energy use. (The formula is the additional space heating required divided by the gross energy savings, expressed as a percentage.) Previous studies have estimated a space heat interaction around 0.5 (Palmiter and Kennedy, 1983; Sherman, 1985). Table 4.5 shows the predictions of net appliance energy savings and space heat interactions from this study. 
Table 4.5. Net Appliance Energy Savings and Space Heat Interaction

\begin{tabular}{lccc} 
& $\begin{array}{c}\text { Cross } \\
\text { Savings } \\
(\mathrm{kWh} / \mathrm{yr})\end{array}$ & $\begin{array}{c}\text { Nut } \\
\text { Savings } \\
(\mathrm{kWh} / \mathrm{yr})\end{array}$ & $\begin{array}{c}\text { Space Heat } \\
\text { Interaction }\end{array}$ \\
\hline $\begin{array}{l}\text { Bascbourd } \\
\text { DHW in Garage }\end{array}$ & 615 & & \\
North & & 454 & 0.26 \\
South & 586 & 471 & 0.23 \\
DHW in Kitchen/L.R. & & 311 & 0.47 \\
North & & 343 & 0.42 \\
South & 615 & & \\
Heat Pump & & 541 & 0.12 \\
DHW in Garage & 586 & 541 & 0.12 \\
North & & 463 & 0.21 \\
South & & 466 & 0.20 \\
DHW in Kitchen/L.R. & & &
\end{tabular}

Notes: 1) Both DHW and refrigerators are included where DHW is in Kitchen/L.R. zone; DHW in garage indicates that heat losses from the DHW are not available in conditioned space, and the interaction applies to the refrigerator only.

2) North indicates the kitchen/living room zone faces north; south indicates the opposite.

3) The difference in gross savings is due to higher shell losses for DHW in unconditioned space.

Because DOE-2 has the ability to model different zones on an hourly basis, the results of this exercise vary somewhat from those produced by whole-house models. The space heat interaction of efficient appliances in a shell-efficient residence muy be less than the commonly accepted value of 0.5 in some cases. The case that replicates most closely a single zone program (like SUNDAY) produces the most similar results. The model of a baseboard system with the DHW in the kitchen/living room zone and north orientation produced a space heat interaction similar to the 0.5 value found in earlier studies. In this case, about half of the waste heat from the appliances would be useful in meeting space heating demands in the kitchen/living room zone.

Space heat interactions are somewhat less for the other cases. The factors that caused lower interactions were:

- DHW located in the garage: waste heat from the DHW tank does not help meet the space heating load in the house.

- Central temperature control: the thermostat for the heat pump system is not in the kitchen/living room zone where most of the appliance waste heat occurs. As modeled, peak temperatures in the living room/kitchen zone exceeded the setpoint temperatlure to a greater extent than the other zones because of the greater concentration of appliances in that zone.

- Southern exposure for the kitchen zone: solar gains reduce the usefulness of appliance waste heat. The difference in orientation is minimal for the heat pump calse, however, probably due to the thermostat being in a different zone than the kitchen/living room. 
This analysis considers only a limited range of typical conditions. Different sizes of homes, insulation levels, climate zones, orientations, and other internal gains would produce different results. However, we believe that more sophisticated models like 1)(O):-2 weuld tend to predict lower space heat interactions than simple, single-zone models like SUNDAY for most conditions. Moreover, lower space heat interactions result in grealler net entergy savings from efficient appliances.

In addition to the factors modeled in this study, other conditions that could lead to lower space heat interactions, and greater net savings from efficient appliances, include:

- Heating systems with lower temperature setpoints, shorter cycles of operation, or higher coefficients of performance.

- Structural characteristics: homes with lower UA values (high insulation levels and low infiltration rates, like those found in the RCDP-2 houses) would lead to lower interactions. Less thermal mass, as in crawl space configurations (as opposed to slab-on-grade) and high solar gains would also decrease interactions (Palmiter and Kennedy, 1983). Finally, the farther away a thermostat is to appliances that generate waste heat, the lower the space heat interaction.

- Warmer weather would decrease the interaction; colder weather would increase it. 


\section{CONCLUSIONS AND REMAINING QUESTIONS}

The sample sizes in this analysis preclude any firm conclusions about savings, or lack thereof, from efficient appliances. However, much useful information was found in the RCDP-2 appliance data. The main conclusions of this study are:

- It is difficult to verify the efficiency of appliances installed in occupied homes.

- Efficient appliances were not readily available at the time RCDP was being implemented.

- The combination of a marketing and an acquisition program (Blue Clue and RCDP) led to minimal savings in the group considered to have efficient appliances, probably because of upgrades in size and features.

- In a comparison of conventional water heaters, differences in energy use based on EF were not significant when corrected for number of occupants. The sample size was small and the variance of the measured data was large enough that expected savings $(305 \mathrm{kWh} /$ year, based on NPPC estimates) were not be detectable.

- Number of occupants was the strongest empirical determinant of DHW energy use. NPPC estimates predict that savings due to efficient end uses $(688 \mathrm{kWh} /$ year from low flow showerheads, efficient dishwashers and clothes washers) are more than twice the savings from efficient tanks ( $305 \mathrm{kWh} /$ year). We were unable to determine water use in this project.

- Exhaust air heat pump water heaters performed much better than conventional water heaters.

- No detectable space heat interactions were found in the measured data. DOE-2 models based on typical conditions indicate that space heat interactions in many homes may be less than currently assumed. Factors leading to lower interactions include location of DHW in the garage, a central heating system, or southern exposure in the kitchen/living room area. Other factors, which were not modeled but which are found throughout the region, may also lead to lower interactions.

Certain issues point to the need for 1) further in-depth research with larger sample sizes and 2) more aggressive efficiency goals for appliance efficiency programs. In conclusion, these are the key questions generated by this research:

- What is the best way to verify that efficient appliances have been installed in program homes? The Appliance Efficiency Group (AEG, a consortium of utilities, state energy offices, and conservation groups in the Northwest) has initiated changes that could facilit appliance efficiency verification. The AEG has contacted the U.S. Federal Trade Commission and manufacturers of residential appliances, encouraging better, more consistent labeling of energy factors, expected energy use, and standard comparisons of efficient and non-efficient models. Actual recommendations are listed in two sample letters included in the Appendix.

- Why was DHW consumption corrected for occupants fairly flat across an EF range of (0.85$0.95 ?$ A large sample size and a research design controlling for number of occupants and volume of water use would be essential in determining the magnitude of energy savings from efficient tanks. 
- Why are some refrigerators--with features that use 70 percent more energy than base models--considered efficient? Or, a related question: Should incentives be employed in appliance efficiency programs, if they encourage the purchase of upgrades that use more energy? Blue Clue efficiency standards (which take into consideration size and features) are probably inappropriate for use in acquisition programs. The structure of incentive programs can lead to unintended consequences, as were found in the RCDP-2 data, where rebates were converted into upgrades. 


\section{REFERENCES}

ASHRAE , 1988. ASHRAE Handbook, Equipment. Atlanta: Amcrican Sociely of lleating, Refrigerating and Air-Conditioning Engineers, Inc.

Byers, Richard. 1989. Cost-Effectiveness of Residential Building Energy' Codes: Results of the' University of Washington Test and the Residential Standards Demonstration Program.

Washington State Energy Office, WAOENG-89-66. December 1989.

Dent, Christopher. 1991. Analysis of Heating System Performance in 472 New Pacific Northwest Homes Built to the Model Conservation Standards. Pacific Science \& Technology for the Oregon Department of Energy. June 1991.

Downey, Peter. 1989. An Analysis of Predicted vs. Monitored Space Heat Energy Use in 83 Homes: Residential Construction Demonstration Project. Washington State Energy Office. August 1989.

Geller, Howard. 1985. Analysis of Minimum Efficiency Standards and Rebate Incentive Programs for Domestic Refrigerators in the Pacific Northwest. BPA Contract Report \#DEAP79-85BP15115. November 1985.

Gordon, Lois and Brrn, David. 1989. Residential Water Heating Qualification Level Analysis. Washington State Energy Office for Bonneville Power Administration. February, 1989.

Nelson, Peter and Short, John. 1990. "Analysis of 12 Japanese Refrigerators in the Northwest." Proceedings of the American Council for and Energy Efficient Economy 1990 Summer Study. Vol. 1, pp. 1.157-1.158.

Northwest Power Planning Council. 1989 Supplement to the 1986 Northwest Conservation and Electric Power Plan. Vol. 2.

Northwest Power Planning Council. 1990. Draft 1991 Northwest Conservation and Electric Power Plan, Volume II, Group 4. Northwest Power Planning Council, November 1990.

Palmiter, Larry and Kennedy, Mike. 1983. "Annual Thermal Utility of Internal Gains," Proceeding of the 8th National Passive Solar Conference. American Solar Energy Society, September 1983.

Pratt, R.G.; Conner, C.C; Richman, E.E.; Ritland, K.G.; Sandusky, W.F.; and Taylor, M.E. 1989. Description of Energy Use in Single-Family Residences in the Pacific Northwest (ELCAP). Pacific Northwest Laboratory for the Bonneville Power Administration. July 1989.

Robison, Dave. 1991. Draft Data from Energy-Efficiency Supply Curve Analysis. Pacific Power and Light.

Sherman, Max; Modera, Mark; and Hekmat, Dariush. 1985. Energy Impacts of Efficient Refrigerators in the Pacific Northwest. Lawrence Berkeley Laboratory for the Bonneville Power Administration. February 1985.

Stovall, T.K. 1987. Hood River Conservation Project Load Analysis. Oak Ridge National Laboratory. ORNL/CON-240, November, 1987. 
Appendix 
RCDP־2 DHW END USE LOAD ANALYYSIS

\begin{tabular}{|c|c|c|c|c|c|c|c|c|}
\hline Date & DHW 1 & & $\begin{array}{l}\text { One } 2 \\
\text { DHW kW }\end{array}$ & & $\begin{array}{l}\text { Zone } 3 \\
\text { DHW kW }\end{array}$ & & $\begin{array}{l}\text { All Zones } \\
\text { DHIW kW }\end{array}$ & \\
\hline Yr-Mo & Effic & Non-eff & Effic & Non-cif & Effic & Non-cif & Efric & Non-eff \\
\hline $88-11$ & 359 & 380 & & & & & 353 & 357 \\
\hline $88-12$ & 375 & 434 & & & & & 391 & 423 \\
\hline $89-1$ & 363 & 47() & 459 & 378 & & & 379 & 441 \\
\hline $89-2$ & 343 & 436 & 439 & 363 & & & 366 & $4(1) 4$ \\
\hline $89-3$ & 373 & 439 & 462 & 396 & 259 & 462 & 391 & 433 \\
\hline $89-4$ & 329 & 385 & 394 & 382 & 272 & 405 & 344 & 389 \\
\hline $89-5$ & 300 & 360 & 374 & 4()() & 282 & 388 & 324 & 376 \\
\hline $89-6$ & 271 & 327 & 305 & 380 & 258 & 357 & 282 & 347 \\
\hline $89-7$ & 261 & 322 & 315 & 358 & 258 & 346 & 281 & 336 \\
\hline $89-8$ & 263 & 308 & 306 & 359 & 257 & 373 & 278 & 336 \\
\hline $89-9$ & 246 & 314 & 324 & 360 & 266 & 384 & 277 & 341 \\
\hline $89-10$ & 289 & 364 & 361 & 400 & 268 & 409 & 312 & 383 \\
\hline $89-11$ & 330 & 386 & 389 & 394 & 293 & 422 & 347 & 397 \\
\hline $89-12$ & 383 & 456 & 455 & 466 & 314 & 461 & 399 & $460)$ \\
\hline $90-1$ & 384 & 455 & 474 & 460 & 330 & 498 & 409 & 466 \\
\hline $90-2$ & 356 & 414 & 419 & 417 & 310 & 437 & 372 & 420 \\
\hline $90-3$ & 358 & 418 & 461 & 445 & 360 & 487 & 395 & 441 \\
\hline $90-4$ & 310 & 360 & 398 & 394 & 326 & 449 & 341 & 391 \\
\hline 4/89-3/90: & & & & & & & & \\
\hline Minimum & 246 & 308 & 305 & 358 & 257 & 346 & 277 & 336 \\
\hline Maximum & 384 & 456 & 474 & 466 & 360 & 498 & 409 & 466 \\
\hline Delta kWh & 138 & 148 & 169 & 108 & 103 & 152 & 132 & 130 \\
\hline Average & 314 & 376 & 381 & 402 & 289 & 414 & 335 & 391 \\
\hline Ave/Max & $81.8 \%$ & $82.4 \%$ & $80.5 \%$ & $86.2 \%$ & $80.3 \%$ & $83.1 \%$ & $81.9 \%$ & $83.9 \%$ \\
\hline
\end{tabular}


